\title{
Henrik Neubauer
}

Višja baletna šola Konservatorija za glasbo in balet v Ljubljani

Akademija za glasbo, Univerza v Ljubljani

Department of Ballet, Conservatory of Music and Ballet, Ljubljana

Academy of Music, University of Ljubljana

\section{Baletna glasba Rista Savina Ballet Music by Risto Savin}

Prejeto: 21. junij 2012

Sprejeto: 14. september 2012

Ključne besede: Risto Savin, balet, Plesna legendica, Čajna punčka, Balet SNG Ljubljana, Balet SNG Maribor

IZVLEČEK

V članku avtor razčlenjuje glasbena dela skladatelja Rista Savina, ki so povezana s plesom oziroma z baletom. Obravnavana so tako tista dela, ki so bila posebej pisana za baletno uprizoritev (baleta Plesna legendica in Čajna punčka), kot tudi Savinove krajše skladbe, ki so po svoji tematiki namenjene plesni izvedbi ali se tej približujejo.
Received: 21st June 2012

Accepted: 14th September 2012

Keywords: Risto Savin, ballet, Plesna Legendica ('Dance Legend'), Čajna punčka ('Tea-Doll'), Ballet of the Slovene National Theatre in Ljubljana, Ballet of the Slovene National Theatre in Maribor

ABstract

The paper discusses Risto Savin's works which have a connection to dance and ballet. The works considered include those which were purposefully intended for a ballet performance (the ballets Plesna Legendica ('Tanzlegendchen', 'Dance Legend') and Čajna punčka ('Une poupée à thé', 'Tea-Doll'), as well as Savin's shorter pieces which are thematically linked to or otherwise close to dance.

\section{Uvod}

Risto Savin je bil vsestranski skladatelj, saj je napisal večje število orkestralnih, komornih, klavirskih skladb, samospevov in zborovskih skladb. Bil pa je med prvimi slovenskimi skladatelji, ki se je posvečal tudi glasbi za gledališki oder. Med njegovimi tovrstnimi deli so ena skladba za dramsko gledališče (Henrik VIII), ki je sicer ni dokončal, štiri opere in dva baleta. Poskusil se je tudi kot dramatik in napisal zgodovinsko dramo Pegam po povesti Frana Detele Pegam in Lambergar.

K njegovi glasbi za baletni oder poleg obeh baletov - Plesne legendice, op. 19 in Čajne punčke, op. 26 - lahko uvrstimo še klavirsko skladbo Pavliha na potovanju, op. 8, ki jo je napisal leta 1894 in je bila prvotno naslovljena Drei Stücke für das Pianoforte (Tri skladbe za klavir), Valse de fleurs op. 28 (klavirska predelava orkestralnega valčka 
iz opere Lepa Vida), Valse lente op. 26 (klavirska predelava enega od stavkov iz C̆ajne punčke) ter Tri baletne valčke za veliki orkester, op. 37.

Tudi te kratke skladbe uvrščamo kot miniature med njegovo baletno glasbo, saj so vse izjemno plesno navdahnjene.

\section{Miniature}

Pavliha na potovanju je Savinova prva klavirska skladba iz leta 1894. Dragotin Cvetko v svoji knjigi iz leta 1949 navaja, da ni izključeno, da je Savin izbral naziv te skladbe pod vplivom simfonične pesnitve R. Straussa Vesele potegavščine Tilla Eulenspiegla, ki jo datira v 1890. ${ }^{1}$ Cvetko se je pri tem zmotil, saj je Straussova skladba nastajala v letih 1894-1895, torej hkrati oziroma še pozneje kot Savinova. Pavliha je seveda znani slovenski šaljivi ljudski junak, ki si ga je na nekoliko drugačen način izbral tudi Viktor Parma leta 1924 za svojo zadnjo opero (Pavliha je pri njem nepismeni župan Kozjedolski). ${ }^{2}$

Savinov Pavliha je sestavljen iz treh slik: prva ima naslov Pavliha pripoveduje, napisana je v obliki scherza v 3/4 taktu in traja približno tri minute in pol. Druga je počasna sarabanda, ki traja dve minuti ter ima naslov Pavliha pri španski plesalki. Tretja slika - Pavlihova koračnica je napisana v 2/4 taktu s šesttaktnim zaključnim prestom. Prav zaradi druge slike - Sarabande - Pavliho najbrž lahko prištevamo k Savinovi plesni glasbi, čeprav v ta namen ni bila uporabljena. V rokopisu Pavlihe je poleg teh treh omenjenih slik v Glasbeni zbirki Narodne in univerzitetne knjižnice v Ljubljani ohranjen še en del - 9/8 Allegretto, ki ga je Savin prvotno načrtoval kot prvo sliko opusa in je tudi naslovljen Pavliha pripoveduje, vendar so vse strani te skladbe prečrtane s svinčnikom. V tiskani obliki je Pavliho na potovanju založila skladateljeva soproga Olga Širca leta 1955 v Žalcu.

Klavirsko skladbo Valse de fleurs (Cvetlični valček) je Savin najprej napisal v orkestralni obliki za drugi prizor drugega dejanja opere Lepa Vida, po vrnitvi druščine s plesa (po Cvetkovi navedbi naj bi se ta skladba najprej pojavila v prvem prizoru drugega dejanja, v prizoru ljubimkanja med služkinjo Ninetto in slugom Giovannijem, in nato še enkrat v začetku drugega prizora). ${ }^{3}$ Pozneje je Savin ta valček predelal v koncertno izdajo za klavir. Tudi to je založila Olga Širca - Savinova v Žalcu leta 1953. Skladba ima sicer naslov Valček, dejansko pa gre za tri valčke - prvi ima naslov Grandioso, drugi je Allegro non troppo tretji Poco più largo (Etwas langsamer). Vsi trije so pisani v tridelni obliki ABA.

Med temi kratkimi skladbami so najbrž najbolj tehtno delo Trije baletni valčki za veliki orkester, ki jih je skladatelj napisal v starosti 80 let. Prvotni naslov je bil Ljubimkanje, (v nemščini Flirt), ki ga je nato zamenjal za Ljubkovanje. V rokopisu je s svinčnikom dodano 3 baletni valčki. Partituro je skladatelj končal 9. februarja 1939, nakar je štirinajst dni pozneje, 23. februarja 1939, skladbo predelal še za klavir. ${ }^{4}$ Tudi ti trije valčki so pisani v

\footnotetext{
V originalu se skladba imenuje Till Eulenspiegels lustige Streiche, op. 28 (1894-95). Dragotin Cvetko, Risto Savin: Osebnost in delo (Ljubljana: Državna založba Slovenije, 1949), 27.

Viktor Parma, Pavliha: komična opera v treh dejanjih (1923-1924). Ker je Parmo prehitela smrt in opere ni uspel dokončati, je delo končal hrvaški skladatelj in kapelnik vojaških godb v Zagrebu Ivo Muhvić.

Cvetko, Risto Savin ..., 78-79.

Datacija je v rokopisu skladbe v Narodna in univerzitetna knjižnica (v nadaljevanju NUK), Ljubljana. Glasbena zbirka. Savin, Risto.
} 
tridelni obliki in spominjajo na koncertantne valčke dunajskega obdobja. Po Cvetkovem mnenju so zvočno zelo pisani in izvrstno instrumentirani. ${ }^{5}$

Obstaja pa še en Savinov valček za klavir in sicer »Valse lente« iz baleta Čajna punčka, ki mu je skladatelj napisal isto številko opusa, 26, kot celotnemu baletu.

Seveda se te miniature že zaradi kratke dolžine ne morejo primerjati z obema njegovima velikima skladbama, ki ju je napisal posebej za izvedbo na baletnem odru.

\section{Plesna legendica}

Prvo delo, ki ga je skladatelj napisal nekaj let po svoji drugi operi, Lepi Vidi, je bila baletna skladba, oziroma kot jo je podnaslovil sam, 'mimična igra v enem dejanju' Plesna legendica (1918). Zamisel zanjo je našel že ob koncu prve svetovne vojne, ko je služboval v avstrijskem Leobnu, in ga je prijatelj opozoril na Sedem legend švicarskega pisatelja in politika Gotfrieda Kellerja ${ }^{6}$ (Dragotin Cvetko navaja da so bile to balade, vendar ta trditev ni pravilna). ${ }^{7}$ Prav zadnjo med njimi, Plesno legendico, si je izbral Savin. V tiskanem scenariju, ki ga je v slovenščini izdala Narodna tiskarna v Ljubljani leta 1922, pred tem pa v nemščini Druck und Verlag: Vytlacil \& Komp. v Leobnu, najbrž leta 1918, je v slovenskem prevodu na kratko povzel Kellerjevo legendo:

Po zapiskih sv. Gregorija je bila Muza plesalka med svetniki. Kot dete dobrih staršev je bila prisrčna devičica, ki je marljivo služila Materi božji ter prepojena s strastjo nepremagljivega veselja do plesa in sicerv toliko, da je plesala nepremotljivo, kadar ni molila. Plesala je Muza na razne načine s svojimi vrstnicami, zotroci, mladeniči, pa tudi sama; plesala je v svoji čumnati, v dvorani, v vrtovih in na livadi. Kadar se je podala k oltarju, je bila pot podobna bolj ljubkemu plesu nego hoji, ter nikdar ni opustila poskušativ naglici malo poplesati na gladkih mramornatih ploščah pred cerkvenimi vrati.

Hkrati je napisal še, da je bila:

podlaga delu ideja, ki se je opetovano izkoriščala a večinoma v pripovedni obliki, pa tudi za gledališki oder. Idejo vodi misel, da je Bogu vsakršno češčenje ljubo, če le pride iz čistega srca.

Ob skladanju tega baleta se je naslonil na podobni temi iz opere francoskega skladatelja Julesa Masseneta Glumač Matere Božje iz leta 1902 in scenske glasbe nemškega skladatelja Engelberta Humperdincka za mistično pantomimo Das Mirakel iz leta $1911 .{ }^{8}$ Prva pripoveduje o godcu oziroma glumaču, ki se zateče v samostan in pleše pred kipom Marije, ki čudežno oživi in ga zaščiti pred ogorčenimi menihi, druga pa o nuni Megildis, ki odide v svet. Marija sestopi iz svoje slike in zavzame njeno mesto. Ko se Megildis vrne, Marija sleče nunsko oblačilo in se spet vrne v sliko.

Risto Savin je seveda Kellerjevo zgodbo priredil po svoje. V tiskanem scenariju je to opisano tako:

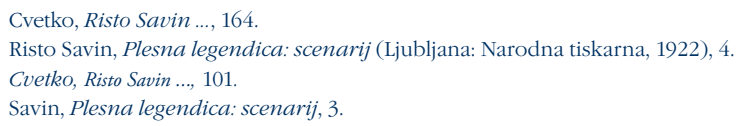


Savin se da inspirirati po Gottfried Kellerjevi legendi istega imena, vendarje pa dejanje sámo prosto izmišljeno ter gre povsem svoja pota. Godba je zložena v obliki suite, katere konec je, dejanju primerno, dramatično razširjen. Uprizoritev zahteva veliki orkester.

Glavna oseba v baletu je Muza, ob njej plešejo še Eros kot ljubezenski zapeljivec, Menih, ki se spremeni v kralja Davida, sv. Marija, sv. Cecilija pa še narod, godci, plešoči (predvsem kmečki) pari, angelci in angeli. ${ }^{9}$ Skladatelj je dal tudi podrobne napotke za prizorišče:

Notranjost kapele v polumraku zahajajočega solnca. Na levi spredaj čudodelni kip sv. Marije stoječ $v$ dubljini stene. $V$ dubljino je vložen zlat mozaik. Okoli dubljine se vije širok venec raznobarunih cvetic. Pred kipom stoji žardinjera (posoda za okrasne rastline - op. p.) s cvetkami v vazah. S stropa visi v modri skodelici večna luč. Najvišja stopnica se razširi v malo ploščo. Vvsako stopnico je vložen ležečželezen meč. Po mečih se hodi samo kleče preko stopnic.

Solnčni žarki, ki prešinejo levo okno, razsvetljujejo prostor pred čudodelno Materjo božjo.

Na desni vzadaj stoje nekoliko vzvišeno orglje, obdane z balustrado (ograja s stebrički - op. p.). Na orgljah, kakor na ograji, so postavljeni angelci. Ti-le drže godala ali liste za note $v$ rokah. Orglje, kakor tudi prostor okoli njih, je skoro da v temi.

Na desni spredaj so stranske duri, ki drže venkaj. ${ }^{10}$

Sledi zelo podroben opis celotnega dogajanja:

Kapela je s prva prazna; potem vstopita z desne Muza in Eros. Muza ima cvetke v laktu.

Eros se nagne ljubko k Muzi, le-ta mu prishǔkava s povešeno glavico. Ko jo hoče Eros nežno objeti in poljubiti, se mu ona rahlo izvije in stopa počasi, še vedno s povešeno glavico h kipu čudodelne Marije.

Muza prišedši $k$ stopnicam, pade na kolena ter opravi molitev v zatopljeni pobožnosti.

Zopet se vspne ter stopa h kipu po stopnicah navzgor ob desni mimo vloženih mečev.

Dospevši na vrh, opazuje najprej vsa ginjena ljubo obličje Marije ter jo začne krasiti scvetkami.

Večkrat prikine svoje delo, stopi malo nazaj, ogledujoč si okraševanje iz daljave. Ob tej priliki prehaja vedno bolj v ritmično gibanje, ki pridobiva kmalu značaj plesa.

$V$ temi na levi se prikaže v obrisih postava - menih gre proti Muzi ter jo prime za roko. Povprašuje deklico radi plesa. Muza mu odgovori, da je nameravala izkazati Mariji s plesom posebno čast.

Potem jo vpraša menih, jeli bi se mogla vsaj jeden dan vzdržati razveseljevanja, nato pa lahko živela vse leto $v$ srčni radosti. ${ }^{11}$

Bi se hotela eno leto odpovedati plesu, lahko pa potem pleše vso svoje življenje kolikokrat in kadarkoli bi to zaželela? Deklica reče: "prav rada bi to storila."

Skladatelj je na tem mestu napisal, da je to povzeto po legendi Kosegartna. Ludwig Theobul (Gotthard) Kosegarten (1758-1818) je bil nemški pesnik in luteranski pridigar. Gottfried Keller naj bi se v svojem delu zgledoval prav po legendah tega pisca. 
Nadalje reče menih: "Bi hotela upustiti ljubezen sveta ter zaničevati minljivo, nečimerno plesanje, da bi nekdaj z Bogom uživala večno življenje, služila ljubi Materi božji ter plesala in rajala z nebeškimi četami?"

Dolgo je molčala deklica ter stokala. Končno reče: "Mali minljivi dobroti na ljubo bi se ne marala plesu odreči, vendar bi se hotela muditi v bližini Boga in sv. Marije ter uživati neskončni ples z njunimi nebeškimi četami."

Povsem bi se morala odpovedati plesu? Tudi je dvomila, če se $v$ nebesih $v$ resnici pleše? ${ }^{12}$

\section{Prikazen.}

Menih se da spoznati, kralj David je. Halja pade raz njega in stoji pred njo $v$ škrlatu kraljeve obleke.

David ji razloži, da je v zmoti v marsikaterem oziru, vendar ji hoče še enkrat pokazati zemeljsko veselje ter ji dovoli tudi vpogled $v$ nebeško veselje. Kadar si je vse temeljito premislila, naj se odloči.

"Poglej tja in voli."

Ozadje se spremeni $v$ transparent. Vidna postaja pokrajinska slika. V sredi stoji senčnato drevo. Pod njim sedi nekaj godcev. Na levi je senčnica, z jasminom obrastena, $v$ koji se mudi zaljubljena dvojica, se poljubi ter stopi nežno objemajoč se iz senčnice. Godci zaigrajo. Dvojica, kateri se pridružijo drugi, prične plesati.

Muza opazuje sliki najprej z zanimanjem, kasneje povesi glavo in zanikuje.

Hitro izgine slika, notranjost kapele postane vidna kot izprva.

\section{Prikazen.}

Ko Muza premišljuje, se zasveti prostor pri orgljah. Angeljci se gibljejo; zibaje pride tudi sveta Cecilija v spremstvu devick orgljam. Sede $k$ orgljam ter prične igratiz devicami in angeljci. Himna $v$ čast $s v$. Marije zadoni.

Zmagala je volja $v$ odpoved in hrepenenje po nadzemeljskem veselju. Muza poda kralju roko ter obljubi, kar zahteva.

Obrnjena proti čudodelni Mariji prisluškuje ginjena deklica godbi, kralj David izgine.

Pri zadnjih taktih Marijine himne pristopi nekaj angeljcev in se pripravijo na muziciranje in ples. Ob koncu himne se prične radosten angeljski ples.

Muza se v začetku zoperstavlja vabam ritmike, pozneje si vidno premaguje plesno veselje, spomnivši se obljube. Vedno slabejši je njen odpor, konečno pa muza docela podleže svoji strasti. Sliši se grmenje iz daljave, kojega pa več ne sliši. Opomin je bil brezuspešen, - Muza začne plesati - prelomila je dano obljubo.

Takoj utihne godba na orgljah. Izginila je sv. Cecilija z devicami in številnimi angeljci; zaostali angeljci pa stoje nepremično na svojih mestih. Prostor pri orgljah otemni.

12 Savin, Plesna legendica: scenarij, 7-8. 
Menda je ugasnilo tudi solnce, ki je pošiljalo svoje žarke iz leve skozi okno. Le zmerno modro razsvetljuje oder svetilna, raz strop viseča. Grom je močnejši, strele prešinjajo zatemneli prostor. Muzin ples postaja hitrejši in strastnejši. Vrti se s besno brzino. Lasje se ji razvežejo ter zakrivajo obličje in ramena,

Eros vstopi in opazuje trenotek kot okamenel ter se zgraža nad početjem ljubljene devojke, potem hiti k Muzi, da jo pomiri in pelje iz cerkve.

Kot blazna se iztrga Muza iz rok Erosa ter divja naprej $v$ kapeli, katero so razsvetile švigajoče strele.

Sliši se vihar. Okna na levi je na vso moč odprl veter, šipa pade žvenketaje na tla.

Ljudstvo išče pred viharjem v kapeli zavetje ter preti divjajoči Muzi. Eros skuša Muzo rešiti a bil je premagan. Plesalko zvežejo na rokah ter jo tiščijo k durim kapele.

$V$ vršečem se prizoru pogleda Muza obupana $h$ kipu Matere božje, iztrga se uporabljajoč zadnje sile iz rok ljudstva, hiti k čudodelnemu kipu, drči po stopnicah na sedmih mečih navzgor, milo proseč z dvignjenimi in zvezanimi rokami Marijinega varstva in obrambe.

Strme ogleduje ljudstvo početje deklice.

\section{Prikazen.}

Kip se razsveti, sv. Marija leskeče v nebeški luči, okovi na deviških rokah zažare in odpadejo. Muza, ki še vedno kleči, se nagne $v$ željnem pričakovanju z razprostrtimi rokami navzad.

V tem je odnehal vihar. V ozadju se pokaže lesketaje razsvetljeno nebo.

$Z$ devicami in angeljci igra zopet sv. Cecilija na orgljah, angelji pohajajo, drugi pa se zibljejo po ritmiki godbe. V neki skupini je videti tudi kralja Davida.

Sv. Marija stopi iz dubljine k deklici na ploščo, prime nežno počasi se dvigajočo Muzo, vodi deklico preko razbeljenih sedem mečev po stopnicah ter plavata proti nebu.

Oder se pokaže polagoma v modrem svitu. V zlatu se bliščeč dež pada iz neba.

Na poti se obrne muza k Erosu, ki je stal ob strani, ogleduje ga, kakor $k$ slovesu ter upira zopet svoje oči $v$ odprto nebo.

Zaman izteguje Eros svoje roke proti ljubljeni devi, ki je zanj izgubljena.

Ljudstvo pade na kolena. Sliši se serafiško petje.

Polagoma izgine nebeška prikazen, notranjost kapele je zopet ista kot v začetku.

V dubljini stoji zopet čudodelna sv. Marija in na plošči pred njo leži - mrtva - Muza, obrnjena s obličjem navzgor. Truplo deklice pa obseva ostra, skozi okno prodirajoča svetloba.

Ljudstvo vstraja na kolenih (Zavesa naglo pade. $)^{13}$

Glasbo v obliki suite je skladatelj, kot omenjeno, napisal za veliki orkester. Klavirski izvleček (priloženo je tudi besedilo v ruščini) je, kot je zabeležil v dataciji rokopisa, končal na Veliki petek leta 1918, ki je glede na rekonstrukcijo koledarja tisto leto nastopil

13 Savin, Plesna legendica: scenarij, 9-12. 
29. marca. Partituro je napisal v naslednjih treh mesecih, saj je na koncu pripisal, da je bila končana na dan Sv. Petra in Pavla istega leta, torej 29. junija. ${ }^{14}$ Orkester sestavljajo tri flavte, piccolo, dve oboi, angleški rog, dva klarineta v A, dva klarineta v B, basklarinet, dva fagota, kontrafagot, štirje rogovi v F, tri trobente v F, tri pozavne, dve pavki, činele, mali boben, triangel, tamburin, dve harfi, celesta, ksilofon, harmonij, mali zvončki in godala (kontrafagot in harmonij je skladatelj predvidel za odrom, da sta zvenela oddaljeno (»enfernt klingend « je zapisal)). V ‘Tretji prikazni’, kjer scenarij zahteva serafično petje, je uporabil še ženski zbor. Zbral je torej vse možne instrumente. To je bilo in je še značilno za vse slovenske skladatelje in zelo otežuje izvedbe, predvsem na manjših odrih. Če je opera ali balet še tako komorna z malo pevsko ali baletno zasedbo, orkester mora biti vedno nadvse velik in polno zaseden, so mislili in še mislijo naši skladatelji.

Plesno legendico so v ljubljanski Operi prvič najavili januarja 1921, ko so napisali, da je:

»Risto Savin predložil gledališki upravi v vprizoritev svojo Plesno legendo, inspirirano po eni Sedmih legend Gottfrieda Kellerja. Zanimiva enodejanka spominja na Massenetovega Glumca naše ljube Gospe ali na Humperdinckov Mirakel. Partitura je pisana za veliki orkester. Delo obeča v mimičnem in glasbenem oziru poseben vžitek in se vprizori najbrž še v letošnji sezoni. «" Do uprizoritve v tej sezoni sicer ni prišlo, so ga pa spet vključili med najave repertoarja za naslednjo sezono 1921/1922.

Premiera je bila nato res v ljubljanski Operi 11. februarja $1922 .{ }^{16}$

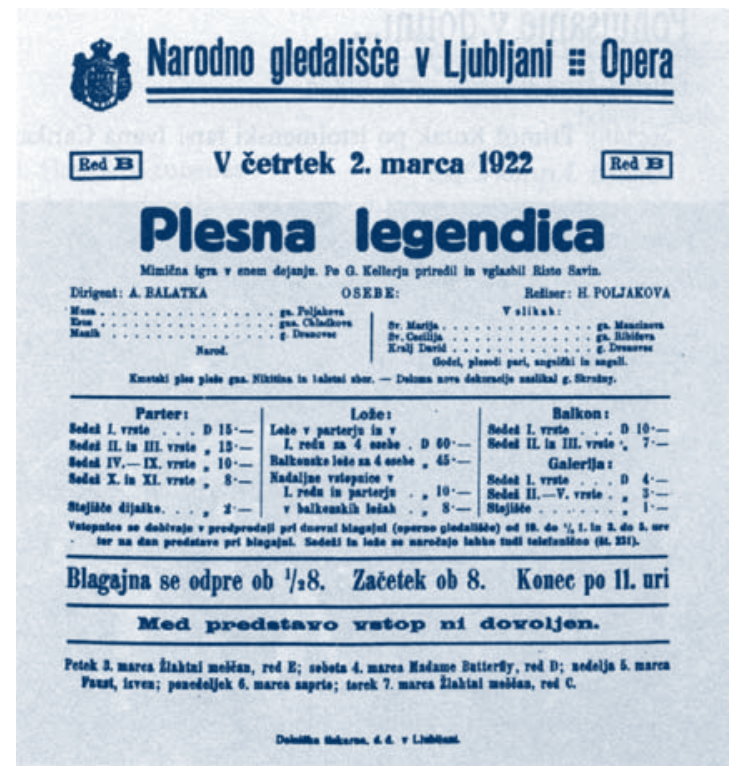

Slika 1: Plesna legendica - letak 1920

Rokopis hrani NUK, Ljubljana. Glasbena zbirka. Savin, Risto.

Gledališki list Narodnega gledališča v Ljubljani, sezona 1920/21, št. 16 (1921): 12

Henrik Neubauer, Razvoj baletne umetnosti v Sloveniji I (Ljubljana: Forma sedem in Društvo baletnih umetnikov Slovenije, 1997), 72 . 
Koreografinja je bila Jelena Dmitrijevna Poljakova (1884-1972), nekdanja prva solistka Mariinskega gledališča v Peterburgu, ki je leta 1908 nastopala tudi z Ano Pavlovo in sodelovala v Ruski baletni sezoni Sergeja Djagileva leta 1910 v Parizu.

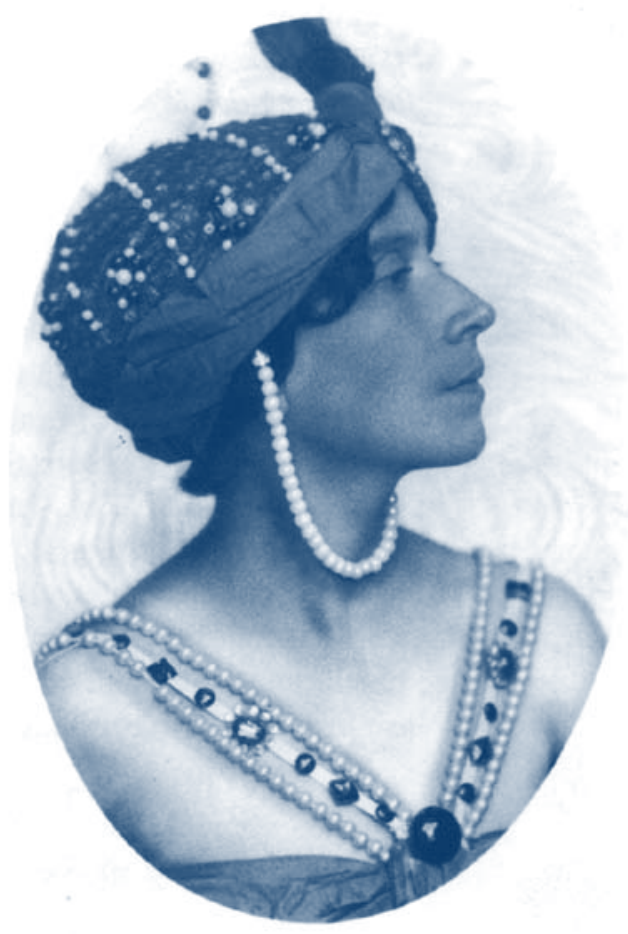

Jelena Poljakova

\section{Slika 2: Jelena Dmitrijeuna Poljakova}

Ljubljanskemu baletnemu ansamblu se je pridružila leta 1920 kot baletna mojstrica in prva plesalka, potem ko je, tako kot mnogi drugi ruski umetniki, po revoluciji odpotovala najprej na Kavkaz, od tam pa je prek Črnega morja in Skopja prišla v Ljubljano. Žal je februarja leta 1922 gledališka uprava odpovedala angažma vsem ruskim umetnikom (z izjemo dramskega režiserja Borisa Putjate). Poljakova je svojo pedagoško in koreografsko pot nadaljevala v Beogradu, med vojno v Avstriji (dunajska Volksopera, Salzburg, Innsbruck), od leta 1947 pa v Čilu, kjer je ostala do smrti. ${ }^{17}$

Plesno legendico je dirigiral Anton Balatka, glavno vlogo Muze je plesala koreografinja, Eros je bila Marija Chladkova, Menih in kralj David član pevskega zbora Joško Drenovec, v posameznih slikah sta nastopili še dve zboristki, Marija Mencinova kot Sv.

${ }_{17}$ Henrik Neubauer, »Jelena Dmitrijevna Poljakova«, v Dokumenti Slovenskega gledališkega muzeja, št. 40 (Ljubljana, 1983). 
Marija, in poznejša znana lirska sopranistka Ivanka Ribičeva kot Sv. Cecilija. ${ }^{18}$ Kmečki ples je ob baletnem zboru, ki je nastopil še v vlogi naroda, godcev, plesočih parov, angelčkov in angelov, plesala takrat trinajstletna Alice Nikitina (1909-1978), ki je prišla v Ljubljano hkrati s svojo baletno pedagoginjo Poljakovo. Baletno kariero je po letu 1922 nadaljevala na Dunaju in v Berlinu, že leta 1923 pa je postala balerina v Djagilevovem Ballets Russes. Pozneje je plesala še v skupini Ane Pavlove in v Ballets Russes de Monte Carlo. Po končani baletni karieri je od leta 1938 nastopala v opernih hišah po Italiji kot koloraturni sopran. Leta 1949 je odprla baletno šolo v Parizu, pozneje pa je delovala v Monte Carlu. ${ }^{19}$ Deloma nove dekoracije je za Plesno legendico naslikal prvi šef slikarne Narodnega gledališča v Ljubljani in ustanovitelj gledališke šole za inscenatorje, Vaclav Skrušny. Isti večer je bila na sporedu še Mascagnijeva opera Cavalleria rusticana. Balet so v sezoni izvedli desetkrat, kar je predstavljalo za takratne čase veliko ponovitev. ${ }^{20} \mathrm{~V}$ Gledališkem listu ob premieri je bilo objavljeno tudi sporočilo skladatelja Rista Savina, ki je podrobno razčlenil svoje misli ob skladbi:

Spomladi, leta 1918, sem ostavil strašno bojno fronto in prišel v ljubko alpsko mestece Ljubno, kjer so me čakali mirnejši posli. Kmalu me je objelo veselje do ustvarjanja in pričel sem iskati dramatičnega osnutka, ki bi odgovarjal moji individualnosti in prilikam odra. Neki moj prijatelj me je opozoril na Gottfrieda Kellerja, in ko sem se seznanil z glavnimi deli plemenitega Švicarja, sem skušal med njimi kaj primernega najti.

Pri tej priložnosti so obvisele moje misli na zadnji izmed dražestnih sedmih legend, in krasna fantastična oseba Muze me je zavzela tako, da sem si jo zamišljal krepkeje in krepkeje tako dolgo, dokler ni stala ljubka deklica živa pred mojimi duševnimi očmi.

Muza se mi je pokazala kot nežno, ljubko, religijozno vzgojeno in tudi pobožno dekletce s fino, bolestno občutlivo dušo in z naivnim in primitivnim občutjem.

Snov se mi je zdela primerna za mimično igro.

K scenariju bi rad dodal nekaj kratkih opazk.

Vzrok navideznega omahovanja, rekel bi iritiranja dejanja, tiči $v$ tem, da sem hotel zgraditi dejanje iz zmesi resnice in vizije in s tem uvesti slušalca $v$ čuvstvovanje Muze.

Ko se prikaže menih, hoče Muza počastiti Marijo s plesom. Resen nastop meniha pa jo iznenadi in zavest krivde jo spravi tako daleč, da spozna v menihu kralja Davida. Gledalec ostavi z njo vred resničnost in sledi viziji.

Ko prekine Muza s plesom drugo vizijo v sceni pri orglah in prekrši dano besedo, se vrne njen duh v resničnost. Ta prehod pospešuje slučajno nastala poletna nevihta.

Zadnjo vizijo z miraklom uvajajo pastirji, ki pobegnejo pred nevihto $v$ cerkev. Tam vidijo besno vrtečo se plesalko in jo hočejo spraviti iz cerkve. Strah pred posledicami prekršene obljube in groza pred pastirji ubogo Muzo popolnoma zmedeta. Z zadnjimi močmi se iztrga pastirjem in hiti h kipu Marije. Po kolenih se preplazi čez sedem stopnic, $v$ katere je vloženih sedem mečev žalostne Matere božje, in prosi za pomoč in varstvo. Toda ta groza je bila za nežno bitje prevelika. Muza umrje.

\footnotetext{
Neubauer, Razvoj baletne umetnosti v Sloveniji I, 72 .

Nikitina by herself (London: Allan Wingate, 1959).

Neubauer, Razvoj baletne umetnosti v Sloveniji I, 73 .
} 
Vzadnjih hipih njenega življenja se ji zdi, da Marijin kip oživi, da se ji bliža Marija, ki jo popelje $v$ nebesa.

Gledalec sledi tretji viziji deklice, pastirji na odru pa je ne vidijo in se trudijo okoli umirajoče Muze.

Glasba je spisana v obliki suite. Ples je zgrajen tako, da spremlja dejanje. ${ }^{21}$

V časopisu Jugoslavija je bilo tri dni po premieri Plesne legendice napisano, da je »občinstvo delo sprejelo pohvalno ter sta se morala skladatelj in glavna plesalka ga. Poljakova opetovano zahvaliti za živahne ovacije. ¿22 $^{22}$

Nekateri drugi časopisi so o tej noviteti poročali obširneje. V Slovenskem narodu 16. februarja 1922 je dal svojo oceno neugotovljeni kritik J. J.:

$»$ V soboto smo imeli v Operi izvirno novost: mimično igro v enem dejanju, ki jo je po Kellerjevi legendi spisal in uglasbil naš operni skladatelj Risto Savin. V glasbenem oziru je ustvaril Savin tu morda svoje najboljše delo: glasba je napisana v obliki suite, je polna globokega čustva, nežne poezije, fine karakterizacije ter je pestra v ritmih. Odlikuje jo prav posebna noblesa; skladatelj se je znal z redkim okusom izogniti vsem opasnostim, da zaide v banalnost, ter se je vzdržal vseskoz na umetniški višini. Manje srečno je dejanje, ki balansira med romantiko in realnostjo; vizionarne slike in končni mirakel so težko umljive, vsaj v naši uprizoritvi. Gotovo je naš oder s svojimi sredstvi še nezadosten, da bi podal poezijo legende v obliki, ki bi prinašala vse prehode tako, da bi ustrezala svobodni domišljiji pesnikovi. Plesnih točk je pravzaprav malo. Gospa Poljakova ima kreirati seveda največji del plesov ter jih je absolvirala kot umetnica zadovoljivo, dasi se v prvi polovici legende ni vselej ozirala na plesne motive skladateljeve. Toda bila je vseskozi poetična pojava velike gracije. Naša primabalerina je bila tu obenem režiserka; morda bi bilo bolje, da v viziji popolnoma izgine cerkveno ozadje z masivnimi stebri; tudi Marijin povratek iz nebes zopet v oltar se naj izvrši spretneje! Množica okoli mrtve Muze je zakrivala sceno! Marija v oltarju pa naj bi se situirala tako, da bo vidna tudi z leve strani. Vobče moramo priznati, da so nam podali gg. Savin, Balatka in Poljakova velik umetniški užitek. «³

V Slovencu pa je K. [Franc Kimovec] 17. februarja 1922 napisal:

"Zopet domača novost, ki je po glasbeni plati vredna pozornosti, zopet en kamen za gradnjo naše »opere« ... Plesna plemenita glasba največ trpi vsled mimične igre, ki ima z glasbo komaj kje kdaj stika. Ga. Poljakova, ki sicer utegne biti izvrstna plesalka kot taka, se prav nič ni vživela niti v legendo samo (to odelo vendar ne more ogrinjati presrčno nedolžne, Devici Mariji služeče devičice, kakor jo legenda tudi v tej obliki označa), pa tudi nič bolj v glasbo kot tako. Ne rečem, da ni bilo semtertje kakega giba, ki bi v svojem zametku morda ne odgovarjal temeljni misli legende, pa je vsak, še preden se je prav rodil, utonil v poplavi razkazovanja plesne spretnosti. Kdor bi hotel tako glasbo prevesti v enako vredno ritmično gibanje, bi moral imeti nekaj duha iz šole Dalcrozeove, zakaj tu ne gre za visoko, dovršeno, absolutno tehniko, ampak za upodabljanje glasbe v telesnih gibih, ki jim po obsegu in obliki jako tesno in na tenko odtehtano odmerja nežni značaj

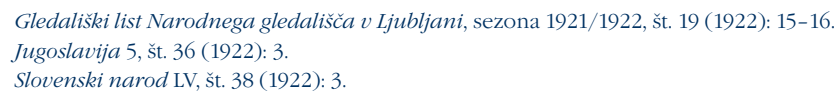


Muze. - Kar naj bi predstavljalo v magični viziji svetno veselje, je seveda učinkovalo prav nasprotno. Za odpoved takemu »veselju« res ni treba prav nič zatajevanja, nasprotno: samo ena želja je človeka prevevala: da bi ga že vendar bilo kmalu konec! Da bi tako tenkočutno bitje ples v prikazni s stališča samo čutne lepote mogel količkaj mikati, je docela neverjetno. Sploh se nam - pač po redkih izkušnjah - vsiljuje sodba, da je naš balet le več ali manj - največkrat manj okusno, oglato premikanje in suvanje; ta večer je bila glasba v očividni opreki. ${ }^{24}$

O tej skladbi je marca 1922 pisal tudi Marij Kogoj. Njegovo razmeroma globoko razmišljanje o plesu in glasbi je zelo zanimivo:

$V$ operi smo zadnji čas imeli priliko slišati in videti noviteto Rista Savina Plesno legendico. Pri tem se je dalo ugotoviti isto kakor pri Lepi Vidi istega komponista. Dobra rutinirana glasba, spretno instrumentirana, vendar brez prave domiselnosti v koncepciji in brez prave izvirnosti v izdelavi. Dobro muziciranje je v delu začetek in konec vsega dobrega. Delo je kot tako zmožno uprizoritve, vendar je scenarium tak, da je za človeka vse zagonetno, da ne rečem neverjetno. Predvsem zame, ki razumem plesno umetnost drugače. Čemu so tej umetnosti historije, gimnastični dialogi in sploh vse, kar očividno nadomešča besedo? Absolutna interpretacija glasbe, njenih oblik, barv, značajev in ritmov je njena stvar. Izražati duševno življenje v poziciji in kretnji posameznika in ansambla in v njih grupaciji in razsvetljavi. Predstavljanje v naši operi je bilo tako malovredno, da ni bilo, lahko se reče niti enega giba, ki bil na eni strani primeren glasbi, a na drugi vsebini in značaju dela ${ }^{25}$

Po teh odzivih sodeč, so bili poročevalci z novim Savinovim delom dokaj zadovoljni, manj pa z njegovo izvedbo. Pri tem bi hotel poudariti, da se je premiera Plesne legendice zgodila pravzaprav ob začetku delovanja ljubljanskega in s tem slovenskega baleta.

Ljubljanski balet je bil namreč ustanovljen takoj po prvi svetovni vojni, jeseni 1918. V prvi sezoni je bil njegov vodja Čeh Vaclav Vlček. Od leta 1919 do 1922 pa ga je nasledil Čeh Vaclav Pohan, ki je z Jeleno Poljakovo izmenoma koreografiral baletne predstave, in predstavil številne balete iz svetovne zakladnice $\mathrm{z}$ razmeroma številčnim 24-članskim ansamblom. V teh treh sezonah so bili na sporedu baleti Coppélia (Léo Delibes), Kraljica lutk (Joseph Bayer), Sanje (različni skladatelji), Gozdne vile (Frédéric Chopin), Od bajke do bajke (Oskar Nedbal), Pieretin pajčolan (Ernö Dohnányi), Šeherezada (Nikolaj Rimski-Korsakov), Labodje jezero (Peter Iljič Čajkovski), prvo slovensko delo Plesna legendica (Risto Savin) in Bajaja (Henrik de Kaan). ${ }^{26}$ Kljub velikemu številu premier ljubljanski baletni ansambel po dobrih treh letih obstoja ni bil še tako izurjen kot pozneje, pa tudi scensko-tehnična sredstva gotovo niso bila dorasla odrsko zahtevnemu Savinovemu delu s prividi - prikaznimi kot jih je v svojem scenariju natančno nakazal skladatelj. Očitno pa je bilo občinstvo in del kritikov s predstavo zadovoljno, kar pa tudi veliko pomeni.

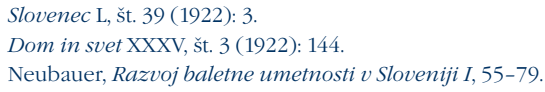




\section{Čajna punčka}

V gledališkem listu za premiero Plesne legendice leta 1922 je bilo navedeno, da: "zlaga Risto Savin zdaj dvoje oderskih del in sicer glasbo k Williama Shakespeareja Henriette Eight [to je bila seveda pomota, v resnici je začel pisati glasbo za tragedijo Henrik VIII) - op. p.] in k baletu Čajna punčka. Zadnja skladba utegne biti tekom poletja gotova. ${ }^{27}$ Res je bil novi balet gotov še celo prej, saj je Rajko Vrečar v celjskem časopisu Nova doba 16. maja 1922 poročal, da je:

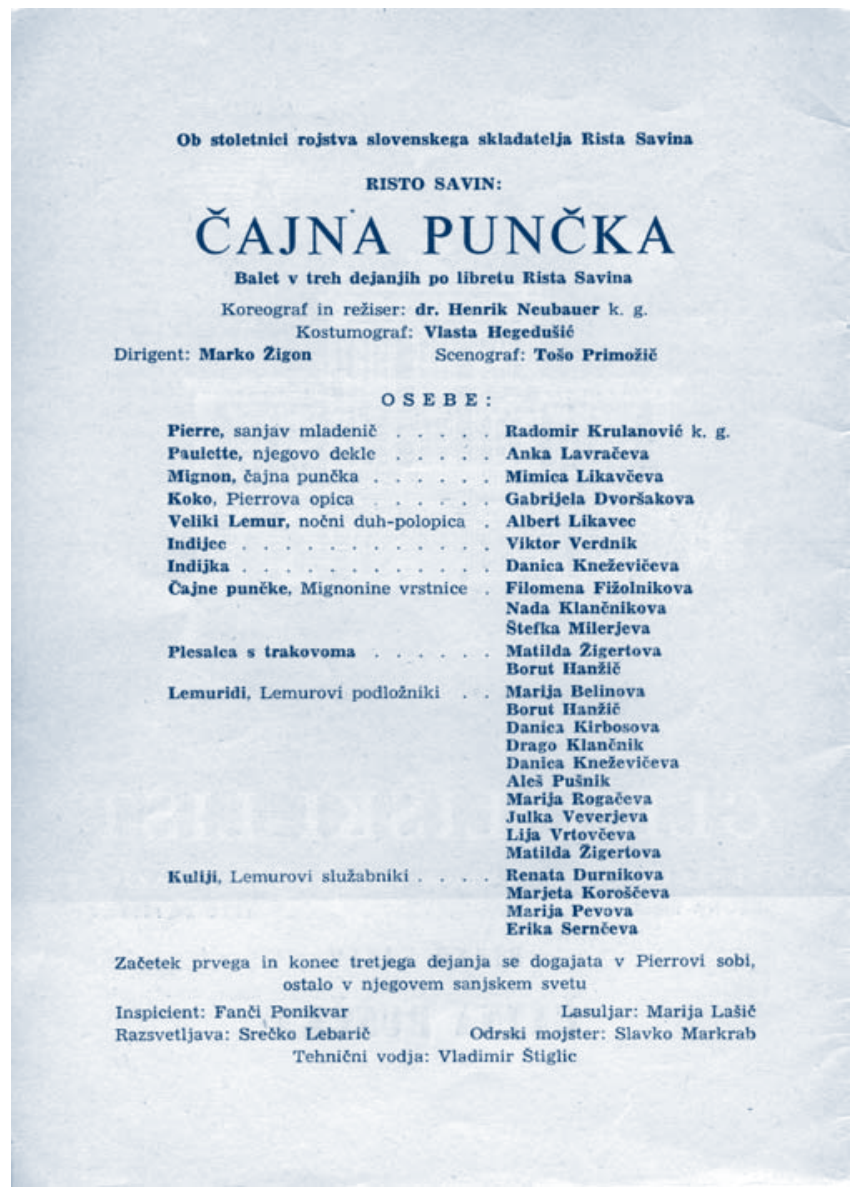

Slika 3: Čajna punčka - zasedba 1959

»Risto Savin zgotovil partituro za veliki orkester, kakor tudi klavirski izvleček prvega po scenariju in glasbi izvirnega jugoslovanskega baleta, imenovan 'Čajna punčka'. Glas-

27 Gledališki list Narodnega gledališča v Ljubljani, sezona 1921/1922, št. 19 (1922): 16 
beno delo tvori jedno celoto v dvanajstih točkah, kojih scenarij se spreminja v jednem dejanju ob odprtem odru. [...] Risto Savin je imel ljubeznivost, predno je izročil ves bogat material nadaljnjim svrhom, ter mi v klavirskem izvlečku pri klavirju pojasnil vso lepo delo ter zajedno tudi vzporedno obrazložil krasno zamišljen in originalen scenarij. « ${ }^{28}$

Koncertna izvedba suite iz tega baleta je bila na sporedu I. simfoničnega koncerta Godbe Dravske divizijske oblasti pod vodstvom dirigenta dr. Josipa Čerina že pol leta po nastanku, 20. novembra 1922. ${ }^{29}$ Takrat so poleg Beethovnove uverture k baletu Prometejeva stvarstva, Dvořakovih Legend op. 59 in Brahmsove Simfonije št. 4 ve-molu, op. 98 izvedli štiri stavke iz Savinovega baleta Čajna punčka op. 26. Naslovi teh so bili: I. Pri podzemnih boginjah, II. Svidenje, III. Pozdrav čajnih punčk, Tempo di menuetto in IV. Marcia. Iz naslova prvega teh stavkov lahko sklepamo, da je skladatelj vsebino pozneje še nekoliko spremenil, saj se podzemne boginje potem v scenariju ne pojavljajo več.

Na krstno odrsko uprizoritev pa je balet moral čakati skoraj 40 let do leta 1959 (11 let po skladateljevi smrti), ko ga je na pobudo dirigenta in direktorja mariborske Opere Jakova Cipcija koreografiral pisec teh vrstic v čast 100-letnice skladateljevega rojstva. Krstna uprizoritev je bila namreč 14 . marca 1959 na odru mariborskega gledališča. ${ }^{30}$

Glasbeno vodstvo je bilo v rokah Marka Žigona, sceno je zasnoval Tošo Primožič, kostume Vlasta Hegedušić.

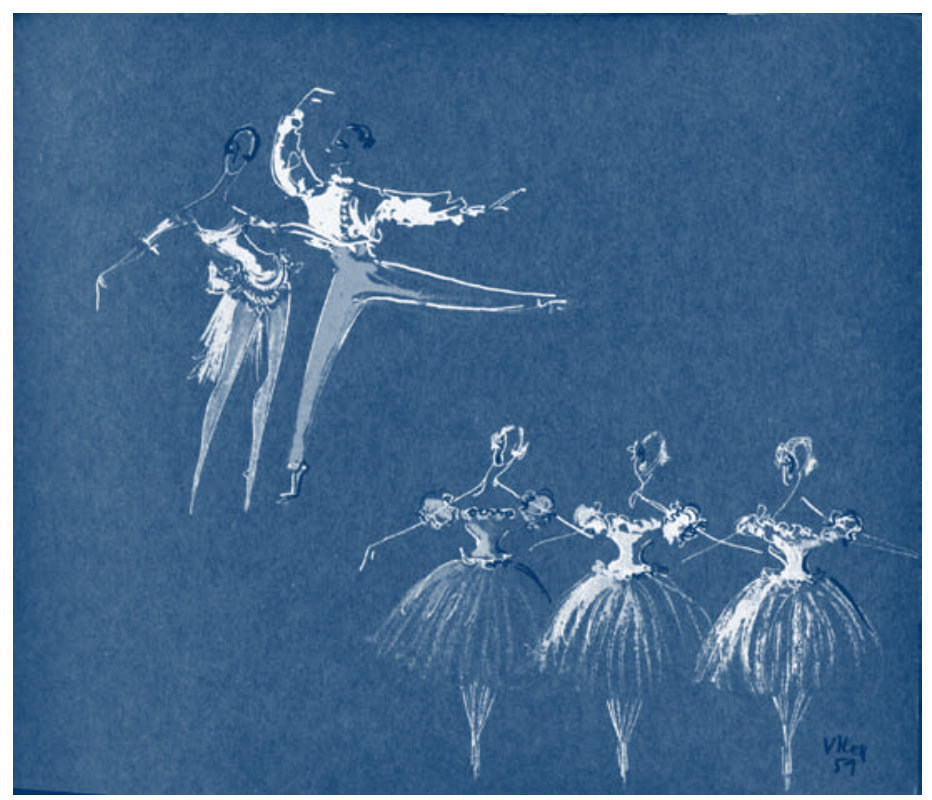

Slika 4: Čajna punčka - kostumski osnutki

Nova doba IV, št. 55 (1922): 3.

Jutro, dnevnik za gospodarstvo, prosveto in politiko 3, št. 274 (1922): 2.

Henrik Neubauer, Razvoj baletne umetnosti v Sloveniji II (Ljubljana: Forma sedem in Društvo baletnih umetnikov Slovenije, 1999), 348. 
Pierra je plesal Rado Krulanović iz Ljubljane (pozneje tudi Viktor Verdnik), Paulette je bila Anka Lavrač, naslovno vlogo Čajne punčke Mignon je plesala Mimica Likavec, Veliki Lemur je bil Albert Likavec, Indijca Viktor Verdnik in Danica Kneževič, plesalca s trakovi Borut Hanžič in Matilda Žigert, čajne punčke Filomena Fižolnik, Nada Klančnik in Štefka Miler, Pierrova opica Koko Gabrijela Dvoršak. Mariborski baletni ansambel je bil takrat številčno majhen in starostno zelo pisan - Lemurovi podložniki so bili Marija Belina, Borut Hanžič, Danica Kirbos, Drago Klančnik, Danica Kneževič, Aleš Pušnik, Marija Rogač, Julka Vever, Lija Vrtovec in Matilda Žigert, zato smo pritegnili še nekatere takrat neangažirane plesalce in naraščaj iz baletne šole (Renato Durnik, Marjeto Korošec, Marijo Pev in Eriko Sernec) kot kulije, Lemurove služabnike.

Skladatelj je o nastanku baleta povedal, da je:

Čajna punčka vezana na intimen osebni spomin. Nekoč sem dobil v dar čajno punčko (darilo njegove poznejše žene - op. p.). Ko sem jo ogledoval, se mi je porodil nekak sen. Ta doživljaj sem pozneje oživil v majhni noveleti, po kateri sem skomponiral balet,

je pripovedoval po navedbi muzikologa Janka Grilca v premierskem gledališkem listu. ${ }^{31}$

Tudi ta balet je skladatelj napisal za veliki orkester z dvema flavtama, pikolom, dvema oboama, angleškim rogom, dvema klarinetoma v B in bas klarinetom v C, dvema fagotoma, rogovi v F, tremi trobentami v F, dvema pozavnama v B, tubo, harfo, timpani, malim bobnom, velikim bobnom, činelami, zvončki, trianglom, ksilofonom, tamburinom, gongom (tamtam) in godali.

Naslov dela je v originalu skladatelj napisal v francoščini - Une poupée à thé, tudi glavne osebe Pierre, Paulette in Mignon imajo francoska imena kot tudi posamezni glasbeni stavki: Introduction (Uvod) - I. Pierrot - II. Mignon (vision en songe (vizija v sanjah)) - III. Pierrette - IV. Lemure - V. Le Chateau-Fort de Grand Lemure (Utrdba velikega lemurja) - VI. Chez les lemurides (Pri lemurjih) - (L'enchanteur des serpents (Krotilec kač)) - VII. Le compliment des poupées à thé (Poklon čajnih punčk) - VIII. Marcia (Koračnica) - IX. Le revoir (Snidenje) - X. La sentence de mort (Smrtna obsodba) - XI. Le bacchanal (Bakanal) - XII. Seul (Sam).

Prvotno enodejanko z dvema prizoriščema, enim v ospredju in enim v ozadju smo zaradi omejenih tehničnih možnosti mariborskega odra pa tudi zaradi bolj preglednega poteka dogajanja spremenili v balet v treh dejanjih (začetek prvega in konec tretjega dejanja v Pierrovi sobi, ostalo na Lemurovem gradu) z dvema odmoroma. Balet je bil tako predstavljen kot samostojen večer, skladateljeva zasnova in ideja pa sta ostali nespremenjeni. 
H. NE U B A U E R - B A L E T N A G L A S B A

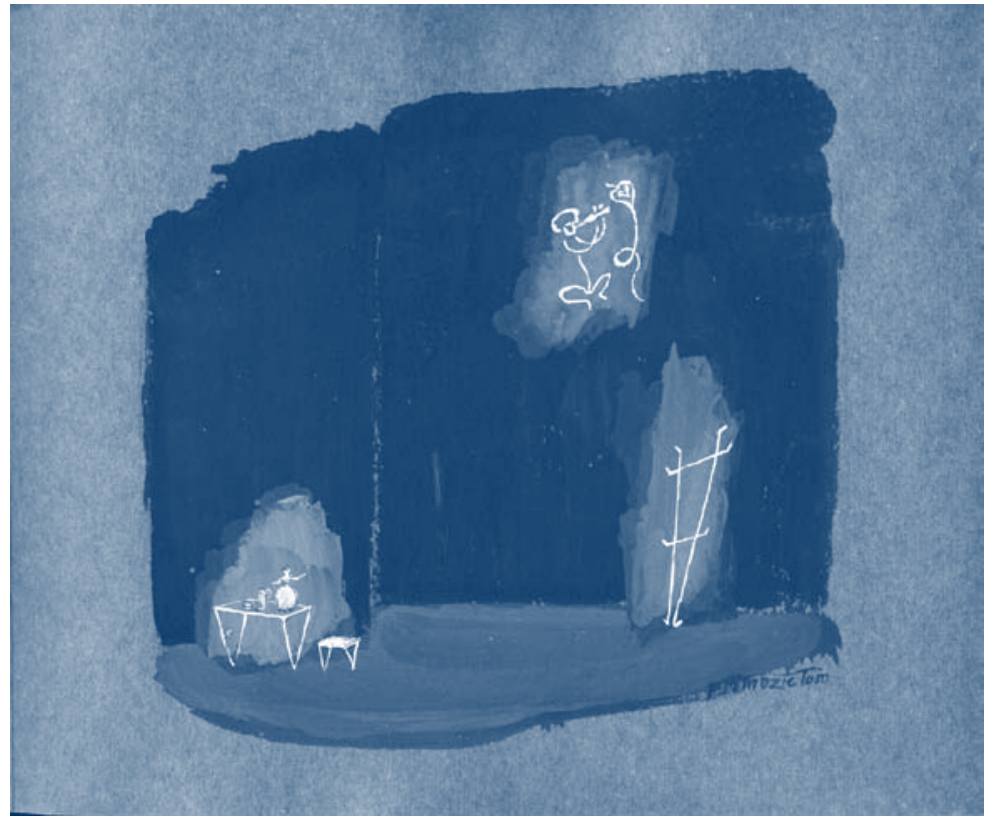

Slika 5: Čajna punčka - scenski osnutek za 1. in 3. dejanje

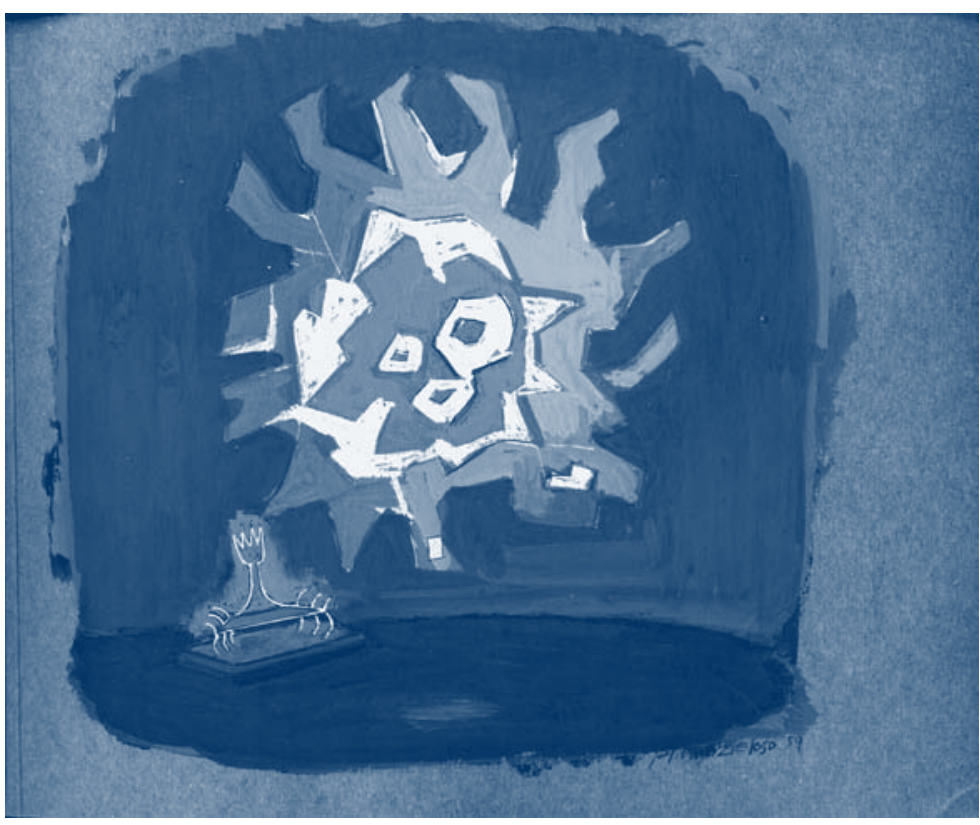

Slika 6: Čajna punčka - scenski osnutek za 2. dejanje 
Savin je Čajno punčko včasih označeval kot balet, včasih kot mimično igro in zato smo se morali, če smo jo hoteli predstaviti kot balet, ogniti nekaterim neplesnim pantomimičnim prizorom in s tem tudi vrsti rekvizitov, od sladkorja, ruma, sveče, fidibusa (papirčka ali trske, ki so jih uporabljali za prižiganje pipe ali sveč - op. p.) do pokalov s pijačo in zlomljene palice kot simbola smrtne obsodbe. Tudi scena je bila bolj preprosta, kot si jo je zamislil avtor, ki je predpisal pohištvo v slogu Ludvika XIV., beneška stekla ipd. Po zamisli scenografa smo vse kulise nadomestili s projekcijo, ki je dala tudi več prostora plesalcem. Razen začetka in konca baleta dogajanje poteka v Pierrovih sanjah in takemu fantastičnemu sanjskemu svetu so ustrezale projekcije, ustrezni pa so bili tudi kostumi. Z vsem tem smo dosegli, da je balet pridobil na razumljivosti in čistosti dogajanja.

Vsebina baleta po zamisli skladatelja, ki smo se je držali, je naslednja:

Pierre, sanjav mladenič, nima dosti družbe in tudi s svojim dekletom Paulette se velikokrat spreta. Večinoma je povod temu punčka, imenovana Mignon, ki pokriva čajnik, da ostane čaj topel. Ta je Pierru zelo pri srcu in mu nadomešča družbo, nanjo pa je Paulette ljubosumna, kljub temu, da je Mignon iz blaga in ima porcelanasto glavico.

1. dejanje: Pierre pride domov v svojo sobo in išče najprej družbo pri Koku, svoji opici, ki pa je zelo razdražljiva in ne mara niti dateljnov iz njegovih rok. Pierre se zateče zato k svoji čajni punčki, pleše z njo in ves zamaknjen v njeno ljubkost zaspi ob mizi.

V sanjah mu njegova punčka oživi, ga pogladi po laseh in prične plesati pred njim. Najprej se mu izmika, končno mu pa le uspe, da jo ujame in zapleše z njo.

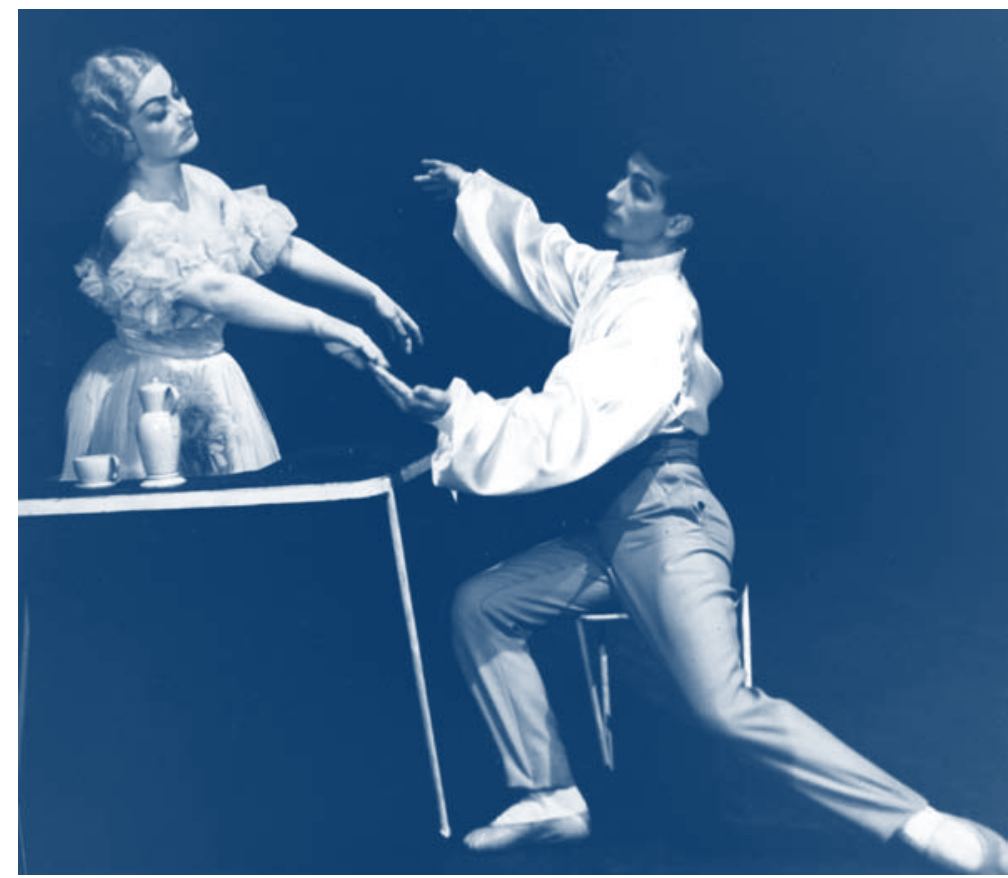

Slika 7: Čajna punčka - Mimica Likavec (Mignon) in Rado Krulanović (Pierre) 
Vtem pride Paulette, vsa razigrana in vesela. Ko opazi Pierra, ga pritegne v svoj ples, vendar le za kratek čas. Komaj se Pierre zopet ozre za Mignon, je že Paulette pozabljena. Ko ga ta še vedno poskuša pridobiti, jo celo grobo odrine. Paulette odide z jezo in grožnjo proti obema.

Pierre in Mignon nadaljujeta svoj ples prve zaljubljenosti in ne opazita nastopanja lemuridov. Zavesta se šele ob prihodu velikega Lemurja, ki ju loči in skuša pridobiti Mignon zase. Ko Pierru le uspe prebiti obroč lemuridov in priti do Mignon, ukaže Lemur, naj ga zvežejo, sam pa nadaljuje s snubljenjem Mignon. Pri tem odstrani s svojo magično močjo zadnjo steno sobe in pokaže Mignon svoj grad. Iz gradu pokliče svoje služabnike, kulije, ki ji prinesejo raznovrsten nakit. Ko pokaže Lemur Mignon še njeno sliko z vsemi dragotinami v zrcalu, se ta vda in privoli na odhod z njim. Še en pogled na ubogega Pierra in razvije se slavnostna povorka v Lemurovo deželo. Nemočen ostane Pierre sam z obupom $v$ srcu.

2. dejanje: Lemuridi plešejo na Lemurovem gradu svoje plese na čast Mignon. Prekine jih nastop Indijca, krotilca kač. Vsi se priklonijo kraljici vseh kač in lemuridi ji s svojim plesom izkažejo občudovanje.

Po odhodu Indijca zapleše svoj ples pred Mignon še Indijka. Na zapoved Lemurja se pojavijo nato tri čajne punčke z darili za Mignon. Njihovemu plesu sledi še ples kulijev, Lemurovih služabnikov, in ples dveh plesalcev s trakovi. Končno zapleše še Lemur z Mignon. Med njunim plesom prinesejo kuliji vladarski prestol, na katerega posadi Lemur Mignon, in vsi lemuridi se jima v vdanosti poklonijo.

3. dejanje: Pierra, ki je ostal zvezan, osvobodi eden izmed lemuridov. Najprej se veseli svobode, a kmalu mu pogled uide na grad, kjer je njegova Mignon. Ravno ko otožen odhaja, pa prihiti Mignon, ki je zbežala z gradu. Najdeta se, a prvo veselje snidenja se kmalu skali zaradi Pierrove ljubosumnosti. Ko pa vidi, da Mignon odvrže ves nakit, da bi mu dokazala svojo ljubezen, ji tudi on odpre svoje srce. Njun ples je vedno bolj zanesen. Mignon pade Pierru v naročje.

A ̌̌e ju je opazil Lemur. Pierre in Mignon skušata uiti, a rešitve ni. Povsod jima zapro pot lemuridi, ki se naslajajo nad njunim obupom. Tedaj se pojavi Paulette, ki takoj izrabi priložnost za maščevanje. Omreži Lemura in ga prepriča, da obsodi Mignon. Obsodba je izrečena, Paulette je dosegla, kar je hotela. Obsodbo mora izvršiti Pierre.

Lemur mu da bodalo in ko se hoče Pierre usmrtiti, mu Lemur vodi roko z bodalom naravnost do Mignoninega srca. Ob zamračenem Pierru Mignon izdihne. Njene vrstnice, čajne punčke, jo objokujejo.

Veselje lemuridov se pokaže v bakanalu, ki ga plešejo. Še ena tožba Pierra in čajnih punčk, a le mrtva Mignonina roka še enkrat omahne prek Pierrovega lica, kot da bi ga pogladila.

Razvije se turobna povorka. Mignonino truplo odnesejo, da ga vržejo prek pečin $v$ morje, in ostale čajne punčke ji slede v smrt. Tedaj se šele Pierre zave in ko ne najde več niti Mignoninega trupla, se z zadnjim obupom vrže na Lemura, ki mu pride na pot. Toda nemočen je. Bori se z njim in medtem, ko v sanjah otepa z rokami, vrže čajno punčko na tla. 


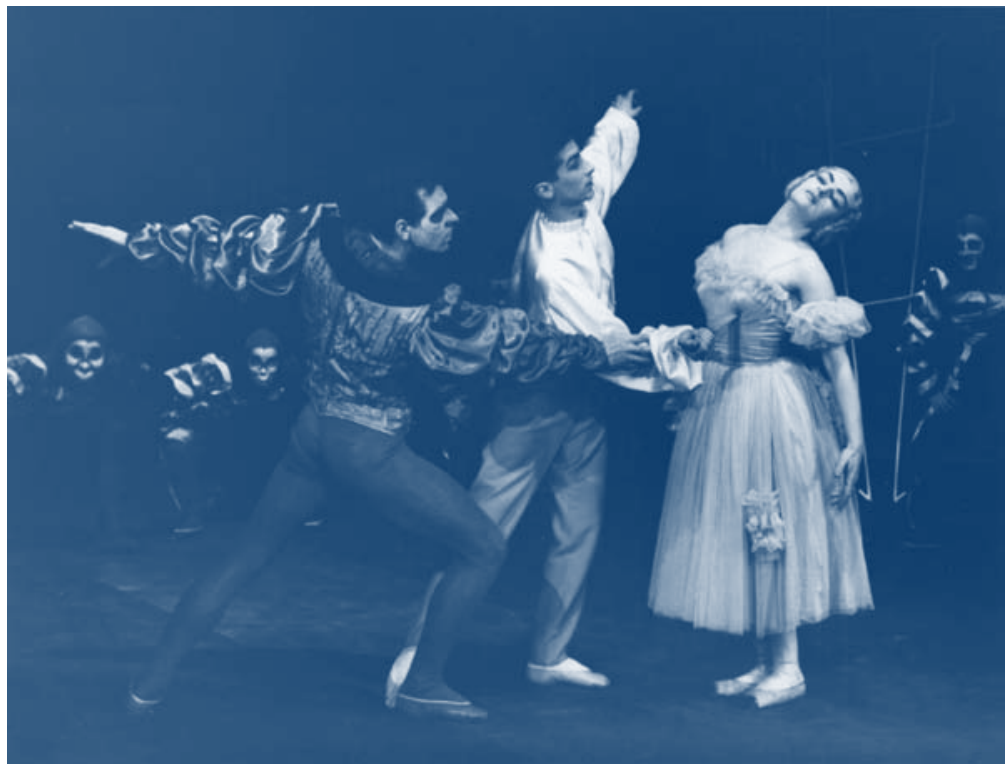

Slika 8: Čajna punčka - Albert Likavec (Lemur), Rado Krulanović (Pierre), Mimica Likavec (Mignon) in ansambel

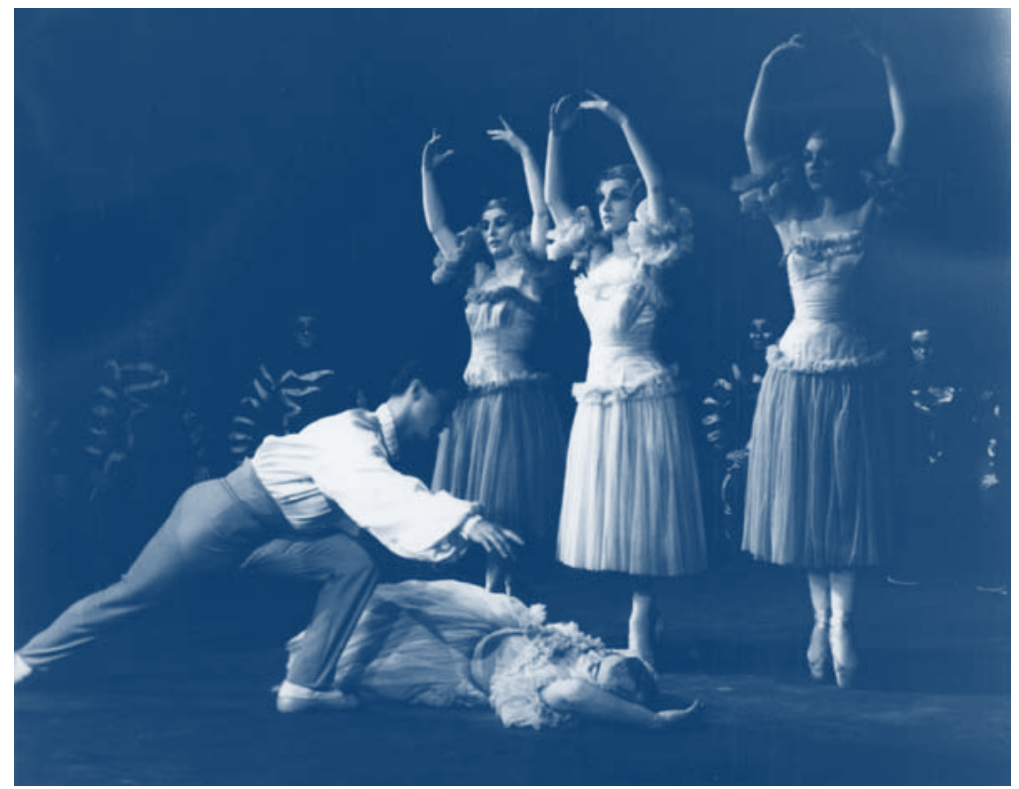

Slika 9: Čajna punčka - Rado Krulanović (Pierre), Mimica Likavec (Mignon), Štefka Miler, Nada Klančnik in Filomena Fižolnik (čajne punčke) 
Zbudi se, sam je $v$ svoji sobi, poleg njega na tleh razbita čajna punčka. In šele ko opazi namrščenega Koka, se spomni strašnih sanj in ves razburjen zapusti sobo. ${ }^{32}$

O predstavi je v Večeru 17. marca 1959 pisal Vlado Golob:

"Težavne naloge postaviti prvič na oder Čajno punčko sta se lotila na pobudo mariborskega opernega vodstva dva mlada poustvarjalca: koreograf H. Neubauer in dirigent M. Žigon. Glede na libreto, glasbo, oder, zmogljivosti našega baletnega ansambla in na finančne možnosti je poizkus gotovo uspel. Koreograf in režiser Neubauer je v sicer malo razgiban libreto vnesel dokaj življenja in mu dal skladen okvir. Ples, ki so ga pokazali glavni solisti R. Krulanović kot gost, M. Likavčeva, A. Likavec in A. Lavračeva ter drugi člani baletnega zbora, sicer ni bil virtuozen, vendar je bil smotrn in dobro naštudiran ter v gibih skladen z glasbo, kar smo doslej pogrešali. Uprizoritev Savinove Čajne punčke je imela trojen uspeh: oddolžili smo se spominu pomembnega slovenskega skladatelja, naš balet je dobil po koreografovi zaslugi izpodbudo za nadaljnje delo in občinstvo je bilo ter bo gotovo tudi v prihodnje $z$ uprizoritvijo zadovoljno. ${ }^{33}$

Slovenski poročevalec je 20. marca 1959 prinesel poročilo Branka Rudolfa: „Baletni večer je uspel in žel precej odobravanja. Glavna zasluga za pomembnost predstave pa gre brez dvoma dr. Neubauerju, ki je koreografiral osupljivo preprosto in sveže. Izrazitost giba mu je bila mnogo ljubša kot sijaj ali tehnična izvedba. Njegov stil se je bližal izraznemu (lahko bi rekli ekspresionističnemu) plesu, ki se je razmahnil kmalu po prvi svetovni vojni, potem pa žal usahnil. Ker si je koreograf očitno prizadeval za osnovnimi prvinami izraznega giba (odboj, vzpon, sklon itd.) in združeval elemente plesne, pantomimične in celo igralske kretnje, je v svojem načinu stopil nekoliko na pot mojstra Labana. Ta stilna sorodnost pa večeru ni škodila, prej nasprotno. Po precej dolgem času je na mariborskem odru spet zaživel ples, ki je z gibi srečno podajal poetično vsebino. Čajna punčka kot plesna stvaritev sicer ni formalno tehnično na kakšni posebni višini, vendar pa ni le poetično prepričevalna, temveč nosi nadih izvirnosti. To je lepa prednost predstave, iz katere lahko vodi pot v prihodnost. «34

V nadaljevanju je poudaril dosežke Rada Krulanovića, Anke Lavrač, Mimice Likavec, Alberta Likavca in omenil še vse ostale nastopajoče.

Čajna punčka je že v sezoni 1958/1959 Mariboru doživela 19 ponovitev, potem pa je mariborski baletni ansambel s to predstavo gostoval še 5. novembra 1959 na Ptuju, 22. novembra 1959 na Ravnah, in 9. januarja 1960 dvakrat v Celju. ${ }^{35}$ V Celjskem tedniku je Slavko Belak 15. 1. 1960 poročal, da je bilo

"gostovanje mariborskega gledališča praznik žive glasbe. V Čajni punčki je prvič zableščala publiki čarobna, silna Savinova glasba. Umetniškemu vodstvu in vsem kreatorjem je treba šteti v posebno odliko, da jo je uprizorilo z vso resnostjo in veliko umetniško zmogljivostjo. Kar pa je treba naglasiti - levji delež 'Čajne punčke' nosi koreograf Neubauer. Saj je glasbo prelil v plesne gibe in ritmično harmonijo. Razdelitev dela v tri dejanja se mi zdi kar posrečena. V mariborski izvedbi bi želeli še premostitev nekaterih

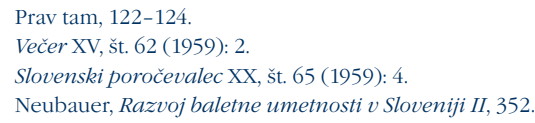


cezur, ki nastajajo ob prelivih slik. Čajna punčka in Savin sta nas ves večer okupirala, očarala je glasba s koreografsko interpretacijo. Nenehno se nemoteno odvija nešteto lepot za oko in uho. Nosilci teh lepot so poleg omenjenega koreografa, dirigent Žigon, plesalci-solisti in baletni zbor. ${ }^{36}$

\section{Sklep}

Žal sta oba Savinova baleta doživela le po eno koreografsko izvedbo. Vendar so bile ocene, vsaj po odrski izvedbi, bolj naklonjene Čajni punčki kot Plesni legendici. Poudarjale pa so glasbeno vrednost obeh skladb v taki meri, da bi bilo najbrž prav, da bi prišlo še do novih interpretacij. Televizija Slovenija je sicer pred leti pripravljala televizijsko predstavitev Čajne punčke, pri kateri naj bi kot oblikovalec scene sodeloval akademski slikar Jože Slak, ki bi gotovo obogatil odrsko podobo baleta, a do realizacije, žal, ni prišlo. Edino kar je od teh priprav ostalo je slušni arhivski posnetek baleta v Arhivu Radia Slovenija, ki ga je leta 1988 posnel Simfonični orkester RTV Slovenija pod vodstvom dirigenta Marka Muniha. En izvod posnetka hrani tudi avtor tega članka. Dva kratka dvominutna prizora pa sta dosegljiva na CD plošči Friderik Širca - Risto Savin, ki je leta 1999 izšla pod uredništvom Suzane Ograjenšek v sozaložbi Založbe kaset in plošč Radiotelevizije Slovenija in Zavoda za kulturo Žalec (SAZAS RSCD 001).

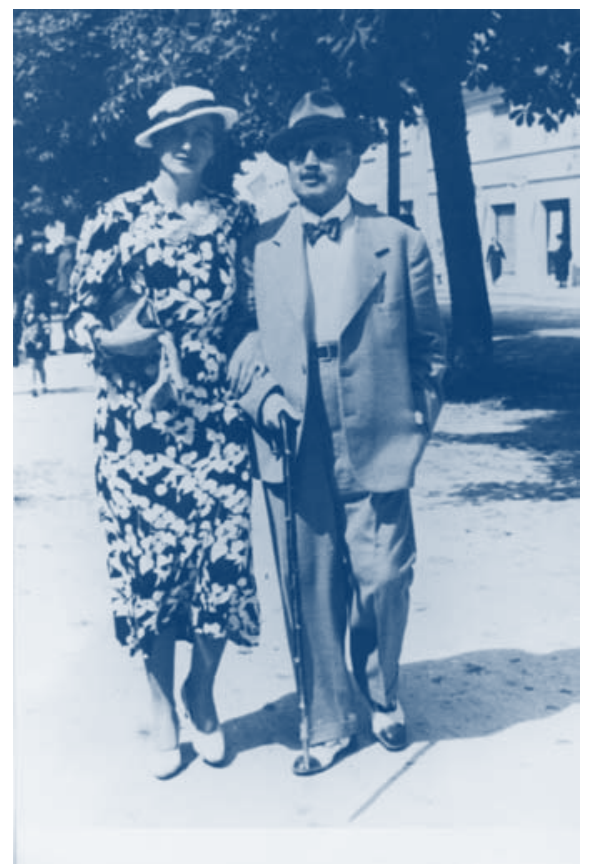

Slika 10: Olga in Friderik Širca

36 Celjski tednik XI, št. 9 (1960): 4. 
Ob koncu te kratke predstavitve ugotavljam, da je Risto Savin posegel prav na vsa področja glasbenega ustvarjanja in da njegova dva baleta skupaj z opisanimi miniaturnimi plesnimi skladbami pričata o njegovi uspešnosti tudi na tem področju. Na moje prvo srečanje s Savinovo glasbo pa mi je ostala ob »rojstni predstavi leta 1959«, kot je napisala prisotna Savinova soproga, Olga Širca, podarjena fotografija.

\section{SummarY}

The paper discusses Risto Savin's works which have a connection to dance and ballet. This includes both his 'grand' ballets, Plesna Legendica ('Tanzlegendchen', 'Dance Legend') and Čajna punčka ('Une pouppe a thé', 'Tea-Doll'), as well as Savin's shorter pieces which are thematically linked to or otherwise close to dance. Among them are several shorter orchestral and piano pieces. First of them is Pavliha na potovanju ('Pavliha on a journey') op. 8 (1894), originally titled Drei Stücke für das Pianoforte ('Tri skladbe za klavir', 'Three Pieces for Piano'), in particular its second movement, Pavliha pri španski plesalki ('Pavliha visits a Spanish Dancer'). The second one, Valse de fleurs op. 28 originated as an orchestral interlude in Act II Scene ii of his opera Lepa Vida, and was later adapted into a concert version for piano.
The weightiest work among the shorter pieces are Trije baletni valčki za veliki orkester ('Three ballet waltzes for grand orchestra') which were originally subtitled 'Ljubimkanje' ('Flirtation', 'Love-Making'; Savin also provided the German title 'Flirt'), later changed to 'Ljubkovanje' ('Caressing'). After finishing the orchestral score Savin also adapted the piece for the piano. Another of Savin's piano waltzes, "Valse lente" op. 26, was adapted from a movement from Čajna punčka and was given the same opus number as the ballet.

For both ballets, Plesna legendica and Čajna punčka, the paper discusses the incentives for their creation and provides a detailed synopsis which includes the composer's instructions. The information on their respective first and only stage performances is also given, listing the production team and the performers, providing illustrations and discussing press reviews. 